\title{
Larger Foraminifera (Alveolinidae, Soritidae and Nummulitidae) from the Former Qulqula Conglomerate Formation, Kurdistan Region, Northeastern Iraq
}

\author{
Imad M. Ghafor \\ Department of Geology \\ College of Science \\ Sulaimani University
}

(Received 11/3/2008, Accepted 31/12/2008)

\begin{abstract}
The most recent studies reformed the occurrence of Qulqula Conglomerate Formation where they combined with Red Bed Series. The present palaeontological study, in the type locality, aids the recognition of the formation. Twenty species from the three families of Alveolinidae, Soritidae and Nummulitidae are described and figured from the former Qulqula Conglomerate Formation (present Red Bed Series) in Kurdistan Region, Northeastern Iraq. These assemblages indicate the age of the source area as Late Paleocene _ Middle Eocene age. The vertical and lateral distributions of the assemblages are discussed. The pebbles and boulders that bearing the recognized assemblages are derived by erosion from the source area (affiliated to Walash _ Naoperdan Group) and deposited during later ages (younger ages) that more likely they deposited during Late Eocene age.

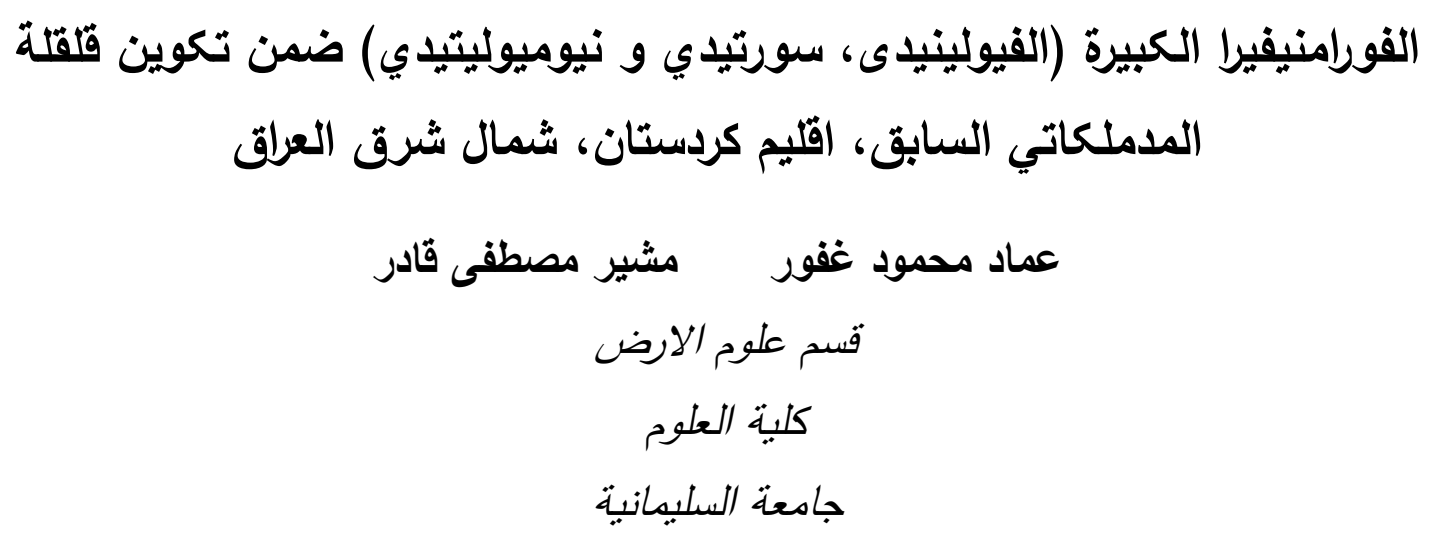


تثير الى كونها قد تعرت من الصخور المصدرية (بعمر الباليوسين المتاخر_ الايوسين الاوسط) والتى قد

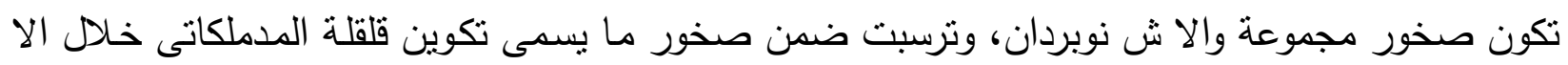
يوسين المتاخر او ما بعد ذاللك.

\section{INTRODUCTION}

The studied area is located within Sulaimani Governorate in northeastern Iraq. It forms a narrow belt extending from Halabja town, in the southeast to Qandil mountain toe near the Qulqula village at the northwest. (Fig.1), this area is located at latitude $\left(36^{\circ} 19^{-} 12^{=}-36^{\circ} 18^{-} 30^{\circ}\right)$ and longitude $\left(45^{\circ} 10^{-} 15^{-}+45^{\circ} 09^{-} 44^{-}\right)$.

The studied area now consist of high mountains which trending northwest southeast, between these mountains there are narrow or wide subsequent (strike) valleys. The mountains and valleys are dissected by; at least, two long consequent valleys and tens of smaller ones. In this area, the Qulqula Group comprise of Qulqula Radiolarian and Qulqula Conglomerate formations. The latter formation is overlying the Qulqula Radiolarian Formation (Buday, 1980). The age and stratigraphic position of this group is controversial because of insufficient studies and complex structure of the occurrence area (Karim, 2003). According to Buday (1980) the Qulqula Conglomerate Formation was firstly described by Bolton in 1955, but a more precise definition and description was given by the same author in (Buday 1958). No changes were introduced in the definition of the formation since that time and no fossils were reported till that time (1980) and the contacts of the formation are not precisely defined and known.

Twelve thin sections from the studied area (Pebbles from Qulqula Conglomerate) were investigated with regard to their content of larger foraminifera.

In this study twenty species of larger foraminifera were described and figured. The stratigraphic distribution and relative abundance of these species in the studied section are given in (Fig. 2).

\section{PREVIOUS WORKS}

Jassim et al., (1984) mentioned that the Cenomanian unit is the equivalent of the Qulqula Conglomerate Formation and they cited that the unit is characterized by the following fossils: Ovalviolina sp., Hemicyclina sigali, Hedbergella washitensis, Hedbergella sp., Thalmanninella ticinensis, T. appenninca, Praealveolina sp., Dicyclina sp. Sissakian, (1997) has shown the formation on the geological map of the Arbeel and Mahabad Quadrangles area. Karim, (2003) cited that the Qulqula Formation (Qulqula Radiolarian Formation) deposited in a subduction trench forming an accretionary prism during the colliding of the Iranian and Arabian plates.

Al-Barzinjy, (2005) mentioned that the lithology of the Red Bed Series is mostly derived from Qulqula Group and Ophiolites. Sissakian, (2005) used Qulqula series instead of Qulqula Group and indicated the environment of the upper part of the series (Qulqula Conglomerate Formation) as marine Eugeosynclinal (flysch type), with age of Cenomanian-Santonian age. 


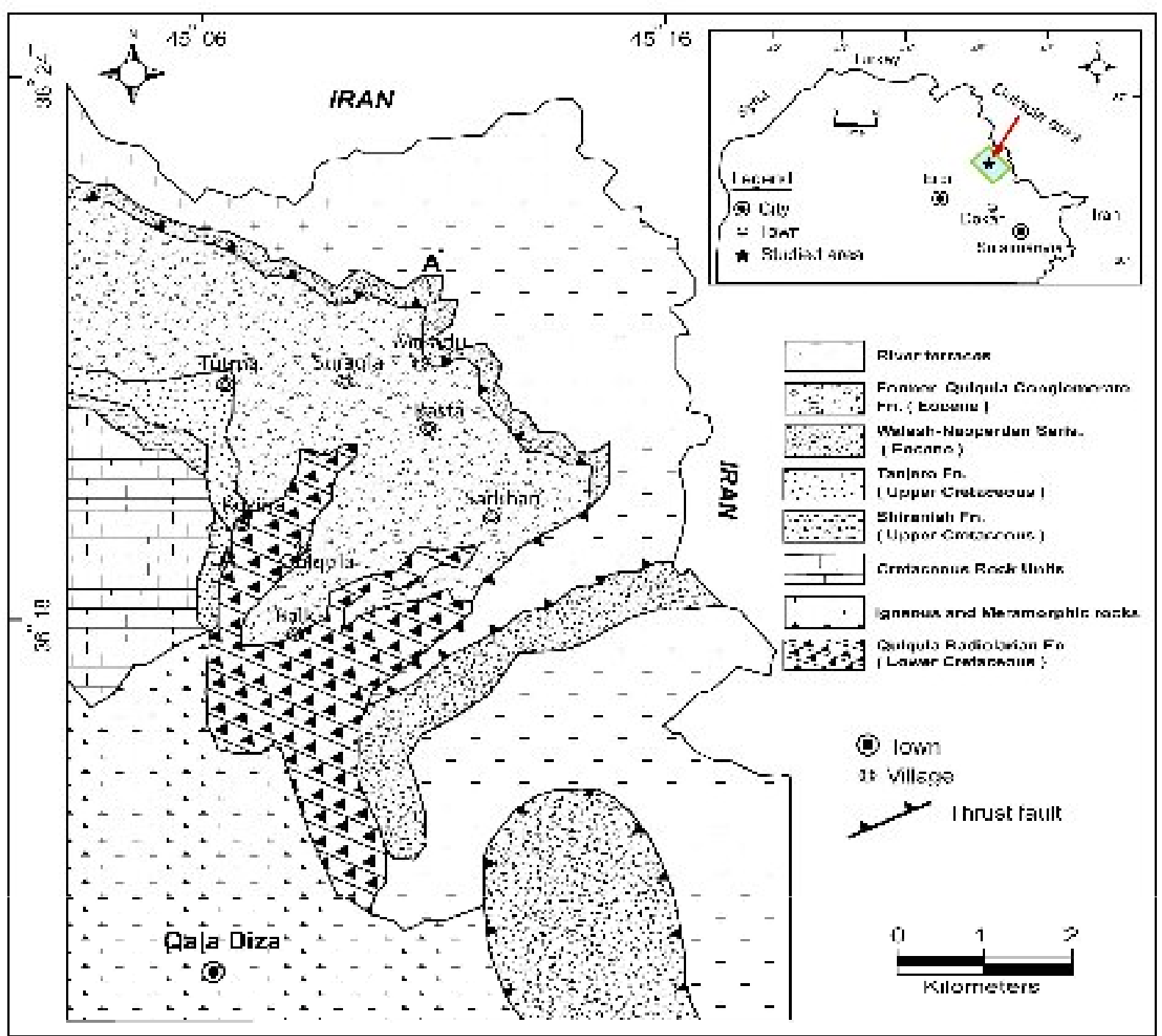

Fig. 1: Location and geological map of studied area (Baziany, 2006).

Baziany (2006) studied the former Qulqula Conglomerate Formation in Sulaimani Governorate in detail and mentioned for the first time numerous well-preserved larger foraminifera Nummulites and Alveolina in the milky pebbles of the conglomerates. He also recognized a clear angular unconformity between the former Qulqula Conglomerate Formation and the underlying Qulqula Radiolarian Formation. He changed the age of the formation from Cenomanian-Santonian to younger than Eocene.

Karim and Baziany, (2007) studied the Qulqula Conglomerate Formation and Red Bed Series at the type area (Qulqula Gorge), NE-Iraq, and they recognized large forams like Alveolina and Nummulite and determined the age of former Qulqula Conglomerate Formation from Paleocene- Eocene. 


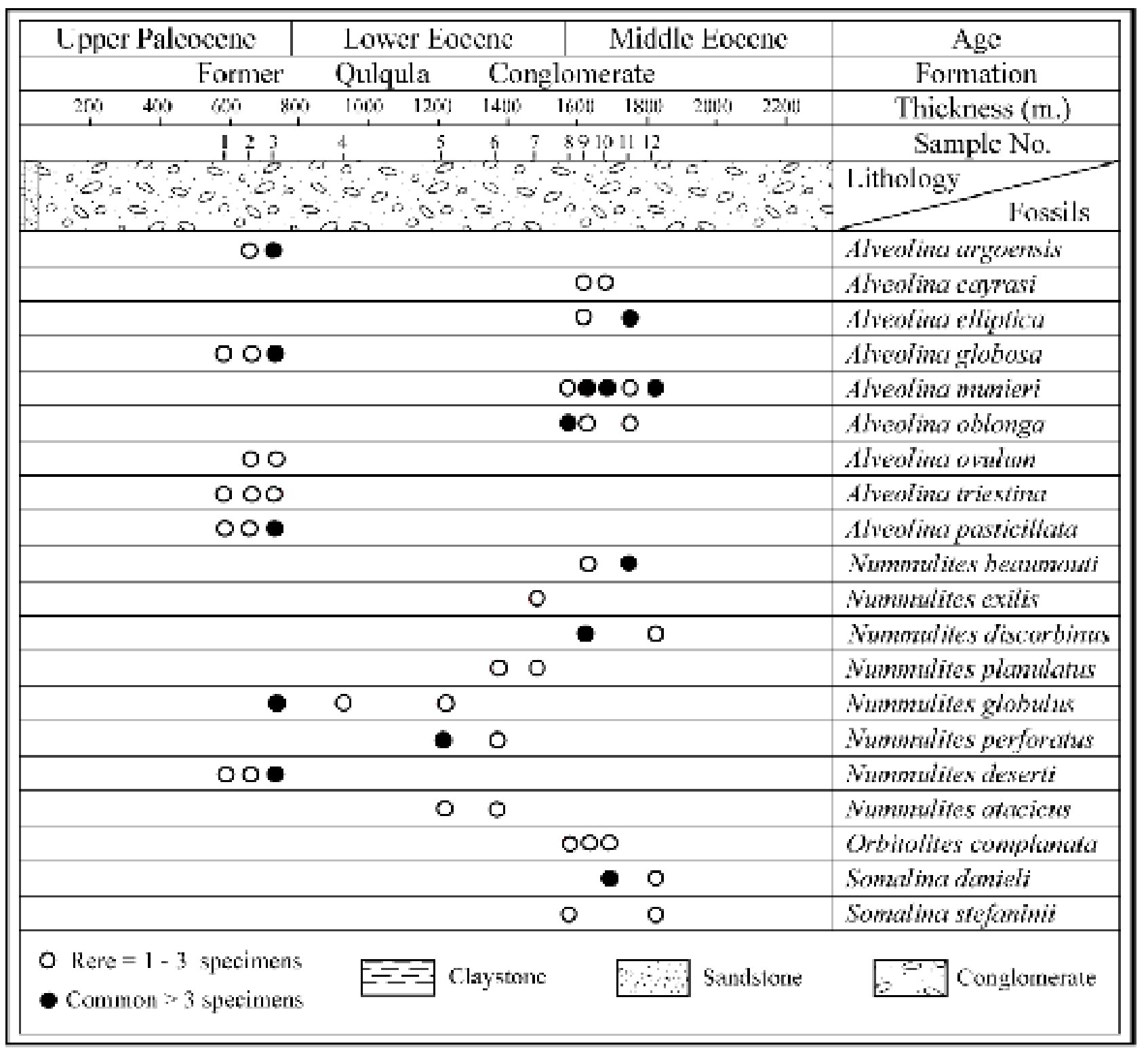

Fig. 2: Distribution of the larger foraminifera in the former Qulqula Conglomerate Formation in the studied area.

Baziany and Karim, (2007) studied the Qulqula Conglomerate Formation that is about $500 \mathrm{~m}$ thick at Halabja-Avroman area. They proved that the large forams like Alveolina and Nummulite are not present in this area. They changed the age of Qulqula Conglomerate Formation, from Albian-Cenomanian, to Quaternary. This is aided by geomorphologic, stratigraphic, structural and sedimentologic evidence. 


\section{SYSTEMATIC DESCRIPTION}

Order: Foraminiferida Eichwald, 1830

Suborder: Miliolina Delage \&Herouard, 1896

Superfamily: Alveolinacea Ehrenberg, 1839

Family: Alveolinidae Ehrenberg, 1839

Genus: Alveolina D'Orbigny, 1826

Type species: Alveolina oblonga D’Orbigny, 1826

\section{Alveolina argonensis Hottinger}

$(\mathrm{P} 1.1 ; 14)$

1960 Alveolina argonensis Hottinger, p.109-111, figs. 60a-f.

1969 Alveolina argonensis Hottinger, Sampo, pls ixxiii, ixxv.

\section{Description:}

Test is elongated to elliptical, wall porcellaneous, imperforate, size large about $(9 \mathrm{~mm})$ in length and $(4.5 \mathrm{~mm})$ in diameter, length / diameter average ratio is $2: 1$, basal wall thin, whorl number up to 16 in numbers, tightly coiled, chamberlets are numerous 20-24 per mm in the last whorl, megalosphere is small.

\section{Occurrences:}

Al-Hashimi and Amer, (1985) reported this species from the Upper Paleocene Sinjar Formation, Northwestern Iraq, in the studied area this species recorded in the Upper Paleocene of the former Qulqula Conglomerate Formation.Sharbazeri,1983 recorded this species from middle Eocene.

\section{Alveolina cayrasi Dizer}

$(\mathrm{P} 1.1 ; 4)$

\section{Description:}

1965 Alveolina cayrasi Dizer, p.274, pl. 3, figs.1-3

Test is cylindrical, with broadly rounded ends, wall porcellaneous, imperforate, size large about $(8.5 \mathrm{~mm})$ in length and $(3 \mathrm{~mm})$ in diameter, length / diameter average ratio is 2.6:1, basal wall thin, whorls up to 24 in numbers, tightly coiled, early whorls are relatively elongated, chamberlets numerous 21-25 per $\mathrm{mm}$ in the last whorl, higher than broader, supplementary chamberlets exist towards last whorls, megalosphere is small.

\section{Remarks:}

In this study $A$. cyarasi Dizer is reported from Middle Eocene. Abawi ana Sharbazeri, (1987) reported A. cyarasi Dizer for the first time from Middle Eocene of Iraq and the Iraqi form differ from the type $A$. cyarasi by its smaller size and by its broadly rounded rather than the description of this species a maximum length up to $(22.1 \mathrm{~mm})$ and a diameter up to $(6.9 \mathrm{~mm})$.

\section{Occurrence:}

A. cyarasi is originally described from the Lower-Middle Eocene of Cayras in Northwest Turkey. Abawi and Sharbazeri, (1987) described this species from the Middle Eocene in the Middle part of the Geli Duhok section, northeastern Iraq. 
This species is rare to common in the former Qulqula Conglomerate Formation.

\section{Alveolina elliptica (Sowerby)}

$(\mathrm{Pl} .1 ; 5,12)$

1840 Fascoilites elliptica Sowerby, Trans. Geol. Soc. London, Ser.2, Vol. 5, pp.329, pl. 18, figs. 17-17a.

1925 Alveolina elliptica (Sowerby), Nuttall, p.378, pl. 20, figs. 1.

1960 Alveolina elliptica (Sowerby), Hottinger, p.146, pl. 121, figs. 1-3.

1974 Alveolina elliptica (Sowerby), Al- Hashimi, p.54, pl. 1, figs. 2-3.

\section{Description:}

Test is cylindrical, with bluntly rounded ends, wall porcellaneous, imperforate, size relatively large attaining $(4.9-6.6 \mathrm{~mm})$ in length and $(2.5-3 \mathrm{~mm})$ in diameter, length / diameter 3average ratio is 2:1, whorl 9-15 in number, chamberlets in a single being higher than broader, numbering 13-16 per $\mathrm{mm}$ in the last whorl, megalosphere is small.

\section{Occurrence:}

Sowerby described this species originally from Cutch in India. Al-Hashimi, (1974) described it from the Middle Eocene Chabd beds of southwest Iraq. It has been also reported from Middle Eocene Naoprdan Shally Group of northeast Iraq. Sharbazheri, (1983) reported this species from the Middle Eocene in the Avanah Formation, northern Iraq. Al-Hashimi and Amer, (1985), Abawi and Sharbazeri, (1987) described it from the Middle Eocene in the middle part of the Geli Duhok section, northeastern Iraq. In the present study, Alveolina elliptica is common in the former Qulqula Conglomerate Formation of the Middle Eocene age.

\section{Alveolina globosa Leymerie}

$(\mathrm{P} 1.1 ; 2,11,13)$

\section{Description:}

1846 Alveolina globosa Leymerie, p.337-373, pl. 13

Test is elliptical to cylindrical, wall porcellaneous, imperforate, size relatively large attaining $(5-6.1 \mathrm{~mm})$ in length and $(3-3.2 \mathrm{~mm})$ in diameter, length / diameter ratio is about $2: 1$, whorl 8-14 in numbers, chamberlets are numerous in the last whorl, megalosphere is small.

\section{Occurrence:}

Al-Hashimi and Amer, (1985), described A. globosa in Sinjar Formation, northern Iraq, of Upper Paleocene. In the present study, A. globosa is common in the Upper Paleocene of the former Qulqula Conglomerate Formation.

\section{Alveolina munieri Hottinger}

(Pl.1; 1, 8, 9)

1960 Alveolina munieri Hottinger, p.165, pl. 16, figs. 16-21, pl. 17, figs. 1-4, pl. 18, figs. 1-4, 18 . 


\section{Description:}

Test is elongate to cylindrical, with rounded to subrounded ends, wall porcellaneous, imperforate, size relatively large attaining (4.5-6mm) in length and (1.2-2.1 mm) in diameter, length / diameter average ratio is 4:1, whorl 12-18 in numbers, tightly coiled, basal wall thin equatorially and thickness towards the poles, chamberlets are numerous and small, supplementary chamberlets exists in adult whorls, megalospheric is small and elongate.

\section{Remarks:}

The Iraqi forams generally have a smaller size and larger number of spires than the original specimen, other characters corresponds well.

\section{Occurrence:}

A. munieri is originally described by Hottinger, (1960) from the Middle Eocene of north Italy. Al-Hashimi and Amer, (1985), reported this species from the Middle Eocene in the Avanah Formation of Geli Dohuk, northern Iraq. Sharbazeri, 1983, Abawi and Sharbazeri, (1987) reported this species as a rare to common in the middle and upper part of Geli Bessri section and in the middle part of Geli Dohuk section (Middle Eocene), northern Iraq. Al-Banna and Al-Mutwali, (2008) recorded it in Walash Group Northeastern Iraq. In the present study, A. munieri is distributed in the former Qulqula Conglomerate Formation as a common in the Middle Eocene.

\section{Alveolina oblonga D'Orbigny}

$$
(\mathrm{P} 1.1 ; 3,6)
$$

1826 Alveolina oblonga D'Orbigny, Tableau methodique, Ann, Sci, Nat. Paris, Ser. 1, Vol. 7, p.306.

1960 Alveolina oblonga D'Orbigny, Hottinger, p.141, pl. 9, figs. 4-16.

\section{Description:}

Test is subcylindrical to elliptical, with broadly rounded ends, wall porcellaneous, imperforate, medium size attaining $(3-4 \mathrm{~mm})$ in length and $(1.1-1.7 \mathrm{~mm})$ in diameter, length / diameter average ratio is 2.2:1, whorl 8-12 in number, chamberlets in single layer $(17-22)$ per $\mathrm{mm}$ in the last whorl, megalosphere is oval, large and attains $171-222 \mu \mathrm{m}$ diameter.

\section{Remarks:}

The investigated specimens are closely related to A. oblonga D'orbigny

\section{Occurrence:}

A. oblonga is originally described from the Lower Eocene of the Paris basin; it is also reported from the Lower Eocene of France, Italy, Spain and Egypt. Al-Hashimi, (1975) reported this species from the Lower Eocene in Naoprdan Group of northeast Iraq. Al -Omari and Sadek, (1975) reported A. cf. oblonga from the Alveolina bearing strata of Middle Eocene age in Dohuk area, northern Iraq. Sharbazheri, (1983) and Abawi and Sharbazeri, (1987) reported this species from Middle Eocene in the Avanah Formation, northern Iraq. In the present studies, A. oblonga is rare in the Middle Eocene of the studied section.

\section{Alveolina ovulum Stache in Schwager}

$(\mathrm{P} 1.1 ; 7)$

1883 Alveolina cf. ovulum Stachein Schwager, p.95, pl. 24, fig. 13-a-c. 


\section{Description:}

Test is ovate to elongate cylindrical, with rounded to subrounded ends, wall porcellaneous, imperforate, size relatively large attaining (3.5-4mm) in length and (1.2-1.8mm) in diameter, length / diameter average ratio is 2.2:1, whorl 7-12 in numbers, chamberlets numerous and in a single layer (6-11) per $\mathrm{mm}$ in the last whorl, megalosphere is oval.

\section{Occurrence:}

A. ovulum is reported in the studied area from Upper Paleocene.

\section{Alveolina triestina Hottinger}

$(\mathrm{Pl} .1 ; 10)$

1960 Alveolina triestina Hottinger, p.1-244, pl. 18, fig. 1-117.1+a-b-c.

\section{Description:}

Test is cylindrical, with subrounded ends, wall porcellaneous, imperforate, size relatively large attaining $(3-4 \mathrm{~mm})$ in length and $(1.2-2 \mathrm{~mm})$ in diameter, length / diameter average ratio is 1:2, whorl 7-11 in numbers, chamberlets numerous and in a single layer $(5-10)$ per $\mathrm{mm}$ in the last whorl, megalosphere is oval.

\section{Occurrence:}

A. triestina in the studied area is recorded from Upper Paleocene in the former Qulqula Conglomerate Formation.

\section{Alveolina pasticillata Schwager}

\section{(P1.1; 15)}

1883 Alveolina pasticillata Schwager, p.79-154, pl. 24-29(1-6).

\section{Description:}

Test is cylindrical, with rounded ends, wall porcellaneous, imperforate, size relatively large attaining $(3-4 \mathrm{~mm})$ in length and $(1.1-1.7 \mathrm{~mm})$ in diameter, length / diameter average ratio is $2.2: 1$, whorl $6-11$ in number, chamberlets numerous, megalosphere is rounded.

Occurrence:

A. pasticillata is reported in the studied area of Upper Paleocene in the former Qulqula Conglomerate Formation.

Suborder: Rotaliina

Superfamily: Nummulitacea de Blainville, 1827

Family: Nummulitidae de Blainville, 1825

Subfamily: Nummulitinae Carpenter, 1850

Genus: Nummulites Lamarck, 1801

Type species: Nummulites laevigatus (Bruguiere) Camerina laevigata Bruguiere, 1792

Nummulites beaumonti D'Archiac and Haime $(\mathrm{P} 1.2 ; 4)$

1853 Nummulites beaumonti D'Archiac and Haime, p.133, pl.5, figs. 1a-c, 2-3

1926 Nummulites beaumonti D'Archiac and Haime Nuttal, p.130, pl.1, figs. 4-5 
1940 Nummulites beaumonti D'Archiac and Haime Davies, p.206, pl.9, figs. 1-9

1959 Nummulites beaumonti D'Archiac and Haime Nagappa, p.180, pl.8, figs. 15-17; pl.9, figs. 1-2

1962 Nummulites beaumonti D'Archiac and Haime Schaub, p.135-196, pl.53, figs. 17-19, 22-25, tab.14p

1965 Nummulites beaumonti D'Archiac and Haime Sen Gupta, p.91-93, pl.15, figs. 1-2, 5; pl.16, figs. 3- 7, 9-10; pl.17, figs. 1,5-7, 12

1972 Nummulites beaumonti D'Archiac and Haime Blondeau, p.149, pl.24, figs.11-14

\section{Description:}

Test is small, thickly lenticuler to biconvex, regularly sloping and sometimes depressive in the ambo. The spherical to subspherical protoconch is followed by a reniform deutroconch of second chamber, and both chambers are followed by closely coiled whorl. The septa are straight or slightly curved. The spiral wall is thick. The diameter varies from $(2.3-3.3 \mathrm{~mm})$ and thickness varies from $(1.6-2.2 \mathrm{~mm})$, the diameter / thickness ratio from 1:1.4-1:2.0.

\section{Remarks:}

This species has small protoconch, a tight coiling of spiral wall, rhombic style of chamber form, and radial septa, which shown in the Numal beat from Egypt, Libya and the type area of the Lower Tertiary rocks of the Pakistan-India region (D'Archaic and Haime, 1853; Nuttall, 1926; Davies, 1940; Nagappa, 1959; Sen Gupta,1965; Matsumaru and Saki, 1989).

\section{Occurrence:}

(Al-Hashimi and Amer, 1985) recorded this species from the Middle Eocene in Iraq, In the studied area it was recorded in Middle Eocene.

\section{Nummulites exilis Douville}

$(\mathrm{P} 1.2 ; 5)$

1919 Nummulites exilis Douville, H., p.1-84, pl. 1, figs. 42; pl. 63, tfs. 10-11; pl. 64, tfs. 12.

1951 Nummulites exilis Douville, Vialli, V., Vol.90, no. 2-3, p.97-168, pl. 5, figs.20-29

1959 Nummulites exilis Douville, Biede, F., p.31-37, (English), pl. 1, figs.5.

\section{Description:}

Test is small, lenticular, biconvex, subspherical protoconch, equatorial periphery circulars, axial periphery acute, the diameter varies from (1.2-2.2mm) and thickness varies from $(0.8-1.7 \mathrm{~mm})$, the diameter / thickness ratio from 1.2:1.6.

\section{Remarks:}

$N$. exilis distinguish from $N$. discorbinus in having smaller and globular test, shape less biconvex, thin lamina.

\section{Occurrence:}

This species recorded from the Lower Eocene in France, (Douville, 1919), Spain (Ruiz, 1948), Poland (Biede, 1959). Al-Hashimi and Amer, (1985) recorded this species from the Lower Eocene in Iraq. Al-Banna and Al-Mutwali, (2008) recorded it in Walash Group Northeastern Iraq. In the studied area this species recorded in Middle Eocene in the former Qulqula Conglomerate Formation. 
Nummulites discorbinus Schlotheim

$(\mathrm{P} 1.2 ; 3)$

1883 Nummulites discorbinus Schlotheim, Harpe, p.de.la, p.1-373, pl. 9, figs. $2 \mathrm{~b}-2 \mathrm{t}, 3$.

1902 Nummulites discorbinus Schlotheim, Martelli, A., Vol.8, p.43-97, pl. 6, (1), figs.4

1928 Nummulites discorbinus Schlotheim, Checchia-Rispoli,G., Vol.53, no.6, p.1-6, pl. 1, figs.9-10.

1954 Nummulites discorbinus Schlotheim, Smont, A. H., p.1-96, pl. 13, (1),figs.4,6-7.

\section{Description:}

Test is small, lenticular to biconvex, spherical to subspherical protoconch, equatorial periphery circulars, axial periphery subacute to acute, the diameter varies from $(1-1.9 \mathrm{~mm})$ and thickness varies from $(0.5-1.5 \mathrm{~mm})$, the diameter / thickness ratio 1.3:1.7:1.

\section{Remarks:}

$N$. discorbines distinguished from $N$. exilis in having larger and more subglobular test, shape more biconvex, thick lamina, rods shaped chambers.

\section{Occurrence:}

This species recorded from the Middle Eocene in Egypt (Harpe, 1883), Italy (Rege, R., 1928), Qatar (Smout, 1954). Al-Hashimi and Amer, (1985) recorded this species in the Middle Eocene in Iraq. In the studied area this species also recorded in Middle Eocene in the former Qulqula Conglomerate Formation.

\section{Nummulites planulatus Lamarck}

(P1.2; 8)

1853 Nummulites planulatus Lamarck, D’Archiac, A. and Haime, p.1-373, pl. 9, figs. 5, 6, 6c, 7b-e.

1926 Nummulites planulatus Lamarck, Nuttall, W.L.F., Vol.63, p.112-120, pl. 10, figs.1-12.

1942 Nummulites planulatus Lamarck, Silvestri,A., Vol.32, Suppl.5, p.1-94, pl. 28, figs. 5.

1960 Nummulites planulatus Lamarck, Cole,W.S., Vol.41, no.190, p.189-205, pl.23, figs. 1,3-4,6; pl. 26, figs.3.

\section{Description:}

Test is medium to large, lenticulars to subglobulars, well preserved specimens, the diameter varies from $(1.2-2.9 \mathrm{~mm})$ and thickness varies from $(0.9-1.8 \mathrm{~mm})$, the diameter / thickness ratio from $1.3: 1: 8$.

\section{Remarks:}

$N$. planulatus varies from $N$. pertrrnats by having large test, large protoconch, more thickned, and more acute chambers.

\section{Occurence:}

N. planulatus recorded from the Lower Eocene in France (Boussac, 1911), Switzerland (Cole, 1960), Spain (Ruiz de Gona, 1948). Al-Hashimi and Amer, (1985) recorded this species from Lower Eocene in Iraq. Al-Mutwali and Abawi, (2001) 
recorded this species from Ratga Formation (Western Iraq) of upper Early Eocene age. In the studied area this species also recorded in Lower Eocene in the former Qulqula Conglomerate Formation.

\section{Nummulites globulus Leymerie}

$(\mathrm{P} 1.2 ; 2)$

1846 Nummulites globulus Leymerie, p.359, pl. 13, figs. 14a-d.

1919 Nummulites globulus Leymerie, Douville, p.54, pl. 1, figs.11-17.

1926 Nummulites planulatus d'Archaic,Doncieux, p.37, pl. 5, figs. 1-7.

1952 Nummulites globulus Leymerie, Azzaroli, p.120, pl. 9, figs. 4, 5.

1959 Nummulites globulus Leymerie, Papp, p.167, text figs. 3c, 4, 5a, b.

1967 Nummulites globulus Leymerie, Nemkov, p.202, pl. 26, figs.1-8.

\section{Description:}

Megalospheric form, external features, Test is small to medium sized, lenticulers to subglobulars, equatorial periphery circulars, axial periphery subacute to acute, well preserved specimens, the diameter varies from $(1-2.8 \mathrm{~mm})$ and thickness varies from (0.6-1.5mm), the diameter / thickness ratio from 1.4:1.7:1.

\section{Remarks:}

N. globulus is distinguished from other Nummulites species in having a larger and subglobulars test, a rather smooth surface, thick lateral laminae, needle shaped chamber cavities. Well marked alar prolongations, distinct and well developed polar plugs.

\section{Occurence:}

Leymeric described $N$. globulus from the Tertiary of France. It was also described from Lower Eocene of the Pyrenees, France by Douville (1919); from the Middle Eocene of Spain by Gomeza lueca (1929); from the Lower to Middle Eocene of Albania by Cizancourt (1931); from the Lower to Middle Eocene of Algeria by Flandrin (1938); from the Paleocene to Lower Eocene of Switzerland by Schaub (1951); from the Lower Eocene of Somaliland by Azzaroli (1952); from the Lower Eocene of Qatar by Smout (1954); from the Lower Eocene of Austria by Papp (1959); from the Lower to Middle Eocene in the Rakhi Nala section of Pakistan by Bayliss (1961) and from the Lower Eocene of the Egypt. (Hamam, 1975), Al-Hashimi (1973) recorded this species from Upper Paleocene to Lower Eocene in northeast Iraq. Al-Mutwali and Abawi, (2001) recorded this species from Ratga Formation (Western Iraq) of upper Early Eocene age. In the studied area this species recorded from Upper Paleocene to Lower Eocene age in the former Qulqula Conglomerate Formation.

\section{Nummulites perforatus Montfort}

$(\mathrm{P} 1.2 ; 7)$

1883 Nummulites perforatus Montfort, pl. 3, figs.1-3

1911 Nummulites bayhariensis Checchia-Rispoli, p.131, pl. 4, figs. 9-11.

1948 Nummulites perforatus Montfort,Van Andel, p.1013 text figs.

\section{Description:}

Test is lenticular, biconvex, equatorial periphery circulars, axial periphery acute to subacute, well preserved specimens, the diameter varies from $(1.1-2.7 \mathrm{~mm})$ and thickness varies from $(0.8-1.7 \mathrm{~mm})$, the diameter / thickness ratio from 1.2:1.5:1. 


\section{Remarks:}

$N$. perforatus is distinguished from $N$. exilis in having smaller and subglobular test, with large proloculus.

\section{Distribution:}

N. perforatus recorded from Lower Eocene in Switzerland (Harpe, 1883); Spain (Gomez, Liueca 1929); Austria (Papp, 1959). Al-Hashimi and Amer, (1985) recorded this species from Lower Eocene in northeast Iraq. In the studied area this species recorded from Lower Eocene age in the former Qulqula Conglomerate Formation.

\section{Nummulites deserti De La Harpe}

$(\mathrm{Pl} .2 ; 1)$

1883 Nummulites deserti De La Harpe, Vol. 30 (Ser.3, Vol.6), Pal. Sect.1, p.155218, pl. 31(2), figs. 239.

1953 Nummulites deserti De La Harpe, LeRoy, L.W, no. 54, p. 1-73, pl.11,figs17-19.

1961 Nummulites deserti De La Harpe, Said, R., and Kerdany, Vol. 7, no. 3, p. 317-336, pl. 326, text figs.7(1a-c).

\section{Description:}

Test is biconvex, lenticulers, spherical to subspherical protoconch, axial periphery subacute to acute, radius varies from $(1.2-1.8 \mathrm{~mm})$ and thickness varies from (0.4-1.6mm), the diameter/ thickness ratio from 1.2:1.6.

\section{Occurence:}

N. deserti is recorded from Eocene in Egypt (Harpe, 1883); Lower Eocene in Egypt (Said and Kerdany, 1961). Al-Hashimi and Amer, (1985) recorded this species from Upper Paleocene in Iraq. In the studied area this species recorded from Upper Paleocene age in the former Qulqula Conglomerate Formation.

\section{Nummulites atacicus Leymerie}

$(\mathrm{P} 1.2 ; 6)$

1846 Nummulites atacicus Leymerie, A., Vol.1 Pt.2, p.337-373, pl. 13, figs. 13b, $13 \mathrm{e}$.

1926 Nummulites atacicus Leymerie, Doncieux, L., Lyon, p. 1-99, pl. 4, figs.1-3.

1939 Nummulites atacicus Leymerie, Silvestri, A., Vol.32, Suppl.4,p.1-102, pl.6,figs. 1 .

1960 Nummulites atacicus Leymerie, Nemkov, G.1. and Barkhatova, No. 5,

\section{Description:} p.29-43, pl. 2 , figs. 7.

Test is lenticuler to biconvex, small to medium sized, lenticuler to subglobular, equatorial periphery circulars, axial periphery subacute to acute, well preserved specimens, the diameter varies from $(1-2.6 \mathrm{~mm})$ and thickness varies from $(0.7-1.6 \mathrm{~mm})$, the diameter / thickness ratio from 1.3:1.6:1.

\section{Remarks:}

$N$. atacicus is distinguished from $N$. discorbinus in having a larger and subglobular test, with large proloculus. 


\section{Distribution:}

$N$. atacicus recorded from Lower Eocene in India (Nuttall, 1925); Switzerland (Schaub, 1951) and Middle Eocene in Italy (Azzaroli 1952). Al-Hashimi and Amer, (1985) recorded this species from Lower Eocene in northeast Iraq. Al-Mutwali and Abawi, (2001) recorded this species from Ratga Formation (Western Iraq) of Upper Early Eocene age In the studied area this species recorded from Lower Eocene age in the former Qulqula Conglomerate Formation.

Family: Soritidae Ehrenberg, 1834

Subfamily: Soritinae Ehrenberg, 1839

Genus: Orbitolites Lamarck, 1801

Type species: Orbitolites complanata SD Douville, 1902

\section{Orbitolites complanata Lamarck}

1801 Orbitolites complanata Lamarck, Systeme des animaux sans vertebres, p. 376.

1925 Orbitolites complanata Lamarck; Nuttall, p. 447.

1939 Orbitolites complanata Lamarck; Silvestri, p. 44, pl. 6, figs. 4-5, pl. 8, fig.1.

\section{Description:}

Test is porcelaneous, discoidal in shape and have numerous chambers which are arranged in successive, annular series; chambers are subdivided into chamberlets separated by thick walls and alternate in position with those of the previous cycle; test is thicker near the periphery than at the centre and is relatively large attaining $(5-8 \mathrm{~mm})$ diameter and $(0.5-1 \mathrm{~mm})$ thickness.

\section{Occurrence:}

This species is originally described from the Eocene of France. The species is worldwide and it is reported from Eocene age of many parts of the world. It has been also reported from Eocene age of Southwest and Northeast of Iraq (Al-Hashimi and Amer, 1985). Al-Omari and Sadek (1975) reported O. cf. complanatus Lamarck from the Middle Eocene Alveolina-bearing strata of Dohuk area. Abawi and Sharbazeri, (1987) reported $O$. complanata in the Middle Eocene from the Avanah Formation, Northern Iraq. In the studied area $O$. complanata is rare to common in the Eocene age.

Genus: Somalina A. Silverstri, 1939

Type species: Somalina stifaninii Silverstri, 1939

Somalina danieli Henson

$(\mathrm{P} 1.2 ; 9)$

\section{Description:}

1950 Somalina danieli Henson, p. 6o, figs. 2-3.

Test is porcelaneous, discoidal to compress lenticular in shape; it is made up of equatorial chamber layer of annular chambers with lateral chamber layers on either side. Equatorial layer is thicker near the periphery than at the center with the chambers arranged alternately; lateral chambers are with minute vacuoles distributed irregularly between successive layers; diameter of the test is $(10-14 \mathrm{~mm})$, thickness is $(1.1 \mathrm{~mm})$ the 
central part and $0.5 \mathrm{~mm}$ near the margin; thickness of the equatorial layer near the margin is $0.32 \mathrm{~mm}$.

\section{Remarks:}

$S$. danieli Henson is distinguished from the closely resembling S. stefaninii Silvestri (1939) by its discoidal rather than lenticular shape and by its smooth surface.

\section{Occurrence:}

Henson, 1950 described S. danieli originally from the Middle Eocene of Southwest Iraq. Buday (1980, p. 225) reported this species from the Middle Eocene Dammam Formation in Iraq. Sharbazeri, 1983 and (Abawi and Sharbazeri, 1987) reported S. danieli from the Middle Eocene in the Avanah Formation, Dohuk area, Northern Iraq. In the studied area $S$. danieli is recorded from the Middle Eocene age.

\section{Somalina stifaninii Silversti}

(P1.2; 11)

1939 Somalina stifaninii n. sp. Silversti, p. 52, figs. 2-3.

1964 Somalina stifaninii Silversti Sampo, pls., ixix, lxxv.

\section{Description:}

Test is porcelaneous, lenticular in shape. Equatorial layer is thicker near the periphery than at the center with the chambers arranged alternately, diameter of the test is $(9-13 \mathrm{~mm})$, and thickness is $(1-1.1 \mathrm{~mm})$ in the central part and $0.4 \mathrm{~mm}$ near the margin.

\section{Remarks:}

S. stifaninii Silversti is distinguished from the closely resembling S. danieli Henson by its lenticular rather than discoidal shape and by its coarse surface.

\section{Occurrence:}

Sharbazheri, 1983 reported this species in the Lower-Middle Eocene in the Avanah Formation, Dohuk area, Northern Iraq. In the studied area S. stifaninii is reported from the Middle Eocene age. 


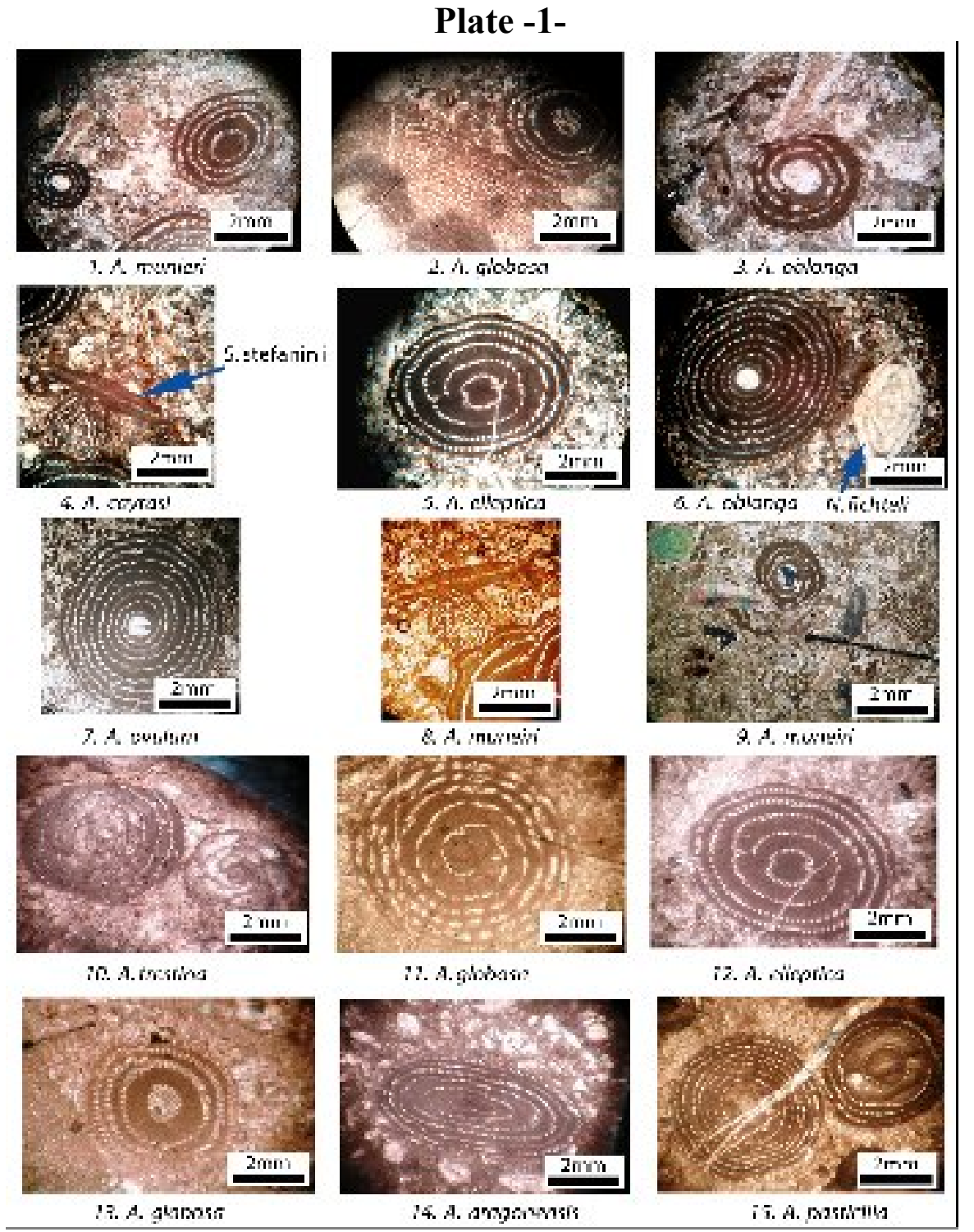

P1.1: Larger foraminifera of the Alveolinidae in the pebbles of former Qulqula Conglomerate Formation in Qulqula gorge:

1,8 and 9. Alveolina munieri Hottinger (M.-Eocene)

1. Axial section, sample No. 9.

8. Equatorial section, sample No.10.

9. Equatorial section, sample No.12.

2, 11, 13. Alveolina globosa Leumerie (U.-Paleocene)

2. Equatorial section, sample No. 1.

11. Equatorial section, sample No. 2.

13. Equatorial section, sample No. 3.

3, 6. Alveolina oblonga D'Orbigny (M.-Eocene)

3. Equatorial section, sample No. 11.

6. Axial section, sample No. 8.

4. Alveolina cayrasi Dizer (M.-Eocene), Equatorial section, sample No.9, x 60.

5, 12. Alveolina elliptica Sowerby (M.-Eocene)

5. Axial section, sample No. 11.

12. Axial section, sample No.8. 
7. Alveolina ovulum (U.-Paleocene), Equatorial section, sample No. 2.

10. Alveolina triestina Hottinger (U.-Paleocene), Equatorial section, sample No.2.

14. Alveolina argoensis Hottinger (U.-Paleocene), Axial section, sample No. 3. 15. Alveolina pasticillata Schwager (U.-Paleocene), Axial section, sample No.1.

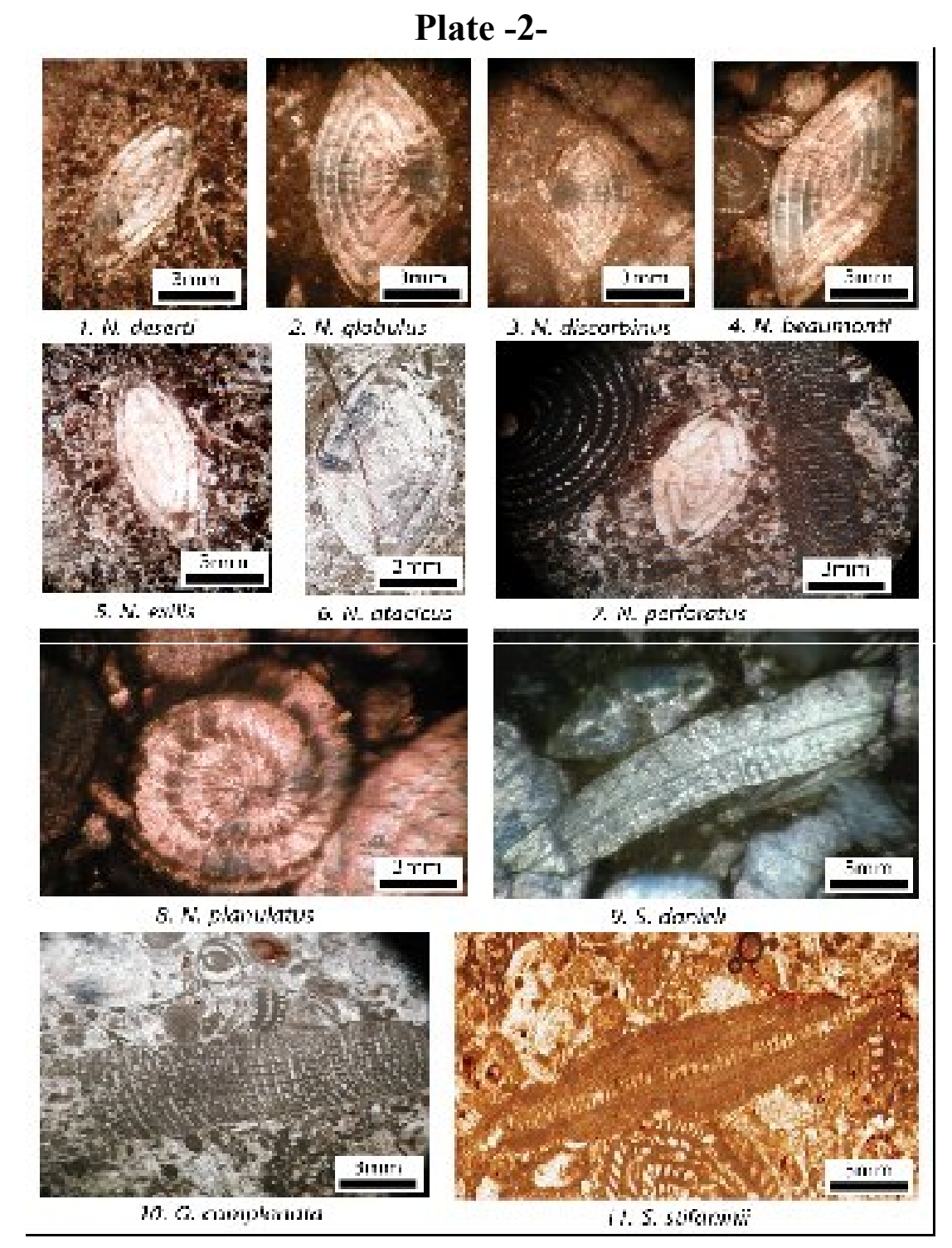

P1.2: Larger foraminifera of the Nummulitidae and Soritidae in the pebbles of former Qulqula Conglomerate Formation in Qulqula gorge:

1. Nummulites deserti De La Harpe (U.-Paleocene), Axial section, sample No.3.

2. Nummulites globulus Leymerie (U.-Paleocene-L.-Eocene), Axial section, sample No.3-4.

3. Nummulites discorbinus Schlothemim (M.-Eocene), Axial section, sample No. 9. 4. Nummulites beaumoti D'Archaic and Haime (M.-Eocene), Axial section, sample No.11.

5. Nummulites exilis Douville (L.-Eocene), Axial section, sample No. 7.

6. Nummulites atacicus Leymerie (L.-Eocene), Axial section, sample No. 6.

7. Nummulites perforatus Montforat (L.-Eocene), Axial section, sample No. 5.

8. Nummulites planulatus Lamarck (L.-Eocene), Equatorial section, sample No.6.

9. Somalina danieli Henson (M.-Eocene), Axial section, sample No.10. 
10. Orbitolites complanata Lamarck (Eocene), Axial section, sample No. 8. 11. Somalina stefaninii Silverstri (M.-Eocene), Axial section, sample No. 9.

The study has the following conclusions

\section{CONCLUSIONS}

1. The pebbles of the former Qulqula Conglomerate Formation (present Red Bed Series) contain larger foraminifera of the Alveolinidae, Nummulitidae and Soritidae families in the type section of the formation.

2. The age of the recorded fossils assemblages range from Upper Paleocene to Middle Eocene age as following:

a. Alveolina assemblages indicator of Upper Paleocene to Middle Eocene.

b. Nummulite assemblages. indicator of Lower to Middle Eocene.

c. Orbitolites assemblages. indicator of Middle Eocene.

d. Somalina assemblages indicator of Lower to Middle Eocene.

3. These assemblages are more likely belong to Walash-Naoprdan source area that deposited during Upper Paleocene to Middle Eocene. While the former Qulqula Conglomerate Formation is deposited during younger age which most possibly coincide with Late Paleocene.

4. The present study aids the rejection of the formation and it combines with Red Bed Series.

\section{REFFERENCES}

Abawi, T.S., and Sharbazeri Kh. M., 1987. Larger Foraminifera from the Avanah Formation (Middle Eocene) of Dohuk area. Northern Iraq. Jour. Geol. Soc. Iraq, Vol. 20, pp. 70-88.

Al-Banna N.Y. and Al-Mutwali M.M., 2008. Microfacies and Age Determination of the Sedimentary Sequences Within Walash Volcanosedimentary Group, Mawat Complex, Northeastern Iraq. in Press, Tikrit Journal of Pure Science.

Al-Barzinjy, S.T.M., 2005. Stratigraphy and Basin Analysis of Red Bed Series From Northeastern Iraq-Kurdistan Region. Unpublished Ph.D. Thesis, University of Sulaimani, Iraq-Kurdistan Region, 159p.

Al-Hashimi, H.A.J., 1973. The Sedimentary Facies and Depositional Environment of the Eocene Dammam and Rus Formations.. Jour. Geol. Soc. Iraq, Vol.VI, pp.1-18.

Al-Hashimi, H.A.J., 1974. Alveolinidae And Rotaliidae From the Eocene Dammam Formation of SW. Iraq. Jour. Geol. Soc. Iraq, Vol.7, pp.51-74.

Al-Hashimi, H.A.J., 1975. Contribution to the Stratigraphy and Micropaleontology of the Naoprdan Shely Group in Chuwarta Area, Northeastern Iraq. Jour. Geol. Soc. Iraq, Special Issue, pp. 27-36.

Al-Hashimi, H.A.J. and Amer R.M., 1985. Tertiary Microfacies of Iraq. DGGSMI. Baghdad. 56p.

Al-Mutwali, M.M. And Abawi, T.S., 2001. Biostratigraphy of the Ratga Formation (Early Eocene) in Selected Wells, Western Iraq, Rafidain Journal of Science, Vol.12, No.3, pp.56-63.

Al-Omari, F.S. and Sadek, A., 1974. Stratigraphy of Alviolina Bearing Strata From Dohuk Area, Northern Iraq, N. Jb. Geol. Palent., Mh., H. 10, pp.577-585. 
Azzaroli, A., 1952. L Macroforaminiferi Della Serie Del Carcar (Eocene Mediae Superiore In Somalia) E La Loro Distribuzione Stratigrafica. Paleontology. Italica, Pisa, Italy, Vol. 47, pp. 99-131.

Bayliss, D.D., 1961. An Investigation of Certain Larger Foraminifera From Pakistan. Unpublished Ph.D. Thesis University. of Wales, 253 P.

Baziany, M.M.Q., 2006. Stratigraphy and Sedimentology of Former Qulqula Conglomerate Formation, Kurdistan Region, NE-Iraq. Unpublished M.Sc. Thesis, University of Sulaimani, Iraq-Kurdistan Region, 103p.

Baziany, M.M.Q. and Karim, K.H., 2007. a New Concept For the Origin of Accumulated Conglomerate, Previously Known as Qulqula Conglomerate Formation at AvromanHalabja Area, NE-Iraq. Iraqi Bulletin of Geology and Mining, Vol. 3, No. 2, pp. 33-41.

Biede, F., 1959. Nummulity Serii Magurskiei Polskisch Karpat Zachoduich (Nummulites of the Magura Series (Polish Western C Arpathians)). Poland Inst. Geol. Biul. Warsaw, No. 131, pp. 5-23 [Polish], pp.24-30 [Russian], pp. 31-37 [English].

Blondeau, A., 1972. Les Nummulites, De L'enseignement Ala Recherché Des Sciences De La Terre. Paris: Vuibert, 254 p.

Buday, T., 1980. Regional Geology of Iraq: Vol. 1, Stratigraphy: I.I.M Kassab and S.Z. Jassim (Eds) D.G. Geol. Surv. Min. Invest. Published. 445p.

Checchia-Rispoli, G., 1911. La Serie Nummulitica Dei Dentorni Di Bagheria in Provincia Di Palermo. Giron Sci. Nat., Palermo, Italy,Vol. 28, pp. 107-200.

Checchia-Rispoli, G., 1928. Dialcane Nummuliti Coceniche Della Marmarica. Italy. Uff. Geol., Boll., Rome, Vol. 53, No. 6, pp. 1-6.

Cizancourt, M. De., 1931. Sur La Stratigraphie La Faune Nummulitique Due Flysch De PAA; Lbanie .Bull. Soc. Geol. Fr. 30,pp.195-212.

Cole, W.S., 1960. The Genus Camerina. Bull. Amer. Pal., Ithaca, N.Y., Vol. 41, No. 190, pp. $189-205$.

D’Archiac, A. And Haime, J., 1853. Description Des Animux Fossilizes Du Groupe Nummulitique De L'Inde Precede D'un Resume Geologique Et D'une Monographie Des Nummulites. Paris: Gide, and J. Baudry, 373 p.

Davies, A.M., 1940. The Upper Kirthar Beds of North-West India.Quart. Geol. Soc. Jour., London, Vol. 96, pp.199-230.

Dizer, A., 1965. Sur Quelques Alveolines De L'Eocene De Turquie. Rev. Micropal., Paris, Vol. 7, No. 4, 274 p.

D'Orbigny, A.D., 1826. Tablean Meshodique De'la Classe Des Cephalopods. Ann. Sci., Nat. Paris, France, Ser.1, Tome.7, pp. 270-307.

Doncieux, L., 1926. Catalogue Descriptif Des Fossils Nummulitiques Des L' Tude Et De L' II Herault; Deuxieme Partie (Fasc.III) Corbieres Septentrionales. Lyon. Unversity. Ann., Lyon, France, N.S.,1.(Sci. Med.) Frsc.45, pp. 1-99.

Douville, H., 1919. L'Eocene Intericur En Aquitane Et Dans Les Pyrenees. France, Serv. Carte Geol. Mem. Paris, pp. 1-84.

Flandrin, J., 1938. Contribution A L'etude Paleontologique Du Nummulitique Algerien. Mate Carte Geol. Alger, Paleont. Vol.8, pp.5-158.

Gomez Llueca, F., 1929. Los Nummulitidos De Espana Mem.Com. Invest. Paleont. Preheist. Madrid, Vol. 36, No. 8, pp. 1-400. 
Hamam, K.A., 1975. Larger Foraminifera From the Lower Eocene of the Gebel Gurnah Luxor, Egypt. J. of Pal;Eontology, Vol.18, Part.1, pp. 161-178.

Harpe, P. De. La., 1883. Monographic Der in Agypten Und Der Libyschen Wuste Vorkommenden Nummuliten. Palentographica (N.S.), Vol. 30, pp.155-216.

Henson, F.R.S., 1950. Mliddle Eastern Tertiary Peneroplidae (Foraminfera), With Remarks on The Phylogeny and Taxonomy of The Family. Wakefield, England, the Author, pp.1-70.

Hottinger, L. 1960. Recherches Sur Les Alveolines Du Paleocsns Et De L' Eocene. Mem. Soc. Paleont. Suisse, Vol. 75/76, pp. 1-244.

Jassim, S.Z., Karim, S.A., Basi, M.A., Al-Mubarak, M.A. and Munir, J., 1984. Final Report on The Regional Geological Survey of Iraq. Vol.3, Stratigraphy, GEOSURV, Baghdad, Lib, Unpublished.Rep.No.1447. 498p.

Karim, K.H., 2003. A Conglomerate Bed As A Possible Lower Boundary of Qulqula Formation, From Chuarta-Said Sadiq Area, NE-Iraq. Kurdistan Acad. Jour. (KAJ), Vol.2. pp.9-18.

Karim, K.H. and Baziany, M.M.Q., 2007. Relation Between Qulqula Conglomerate Formation and Red Bed Series, at Qulqula Area, NE-Iraq. Iraqi Journal of Earth Sciences, Vol.7, No.1, pp.1-12.

Lamarck, J.B., 1981. Systeme Des Animaux Sans Vertebres. Paris: Published By The Author, pp.1-432.

Leroy, L.W., 1953. Biostratigraphy of The Mafi Section, Egypt Geol. Soc. Amre., Mem., N.Y., No. 54, pp. 1-73.

Leymerie, A., 1846. Memorie Sur Le Terraina a Nummulites (Epicretaic) Des Corbieres Et Dela Montagen Noire, Mem, Soc. Geol. Fr 1(2), pp.337-373.

Martelli, A., 1902. L Fossili Dei Terreni Eocenici Di Spalata In Dolmazia. Paleontogr. Italica, Pisa. Italy, Vol.8, pp. 43-97.

Matsumaru, K. and Sakai, H., 1989. Nummulites and Assilina From Tansen Area, Palpa District, Trans Proc. Paleont. N.S., No. 154, pp. 68-76.

Nagappa, Y., 1959. Foraminiferal Biostratigraphy of the Cretaceous-Eocene Succession in the India Pakistan-Burma Region. Micropaleontology. Vol. 5, No.2, pp.145-192.

Nemkov, G.J., 1967. Remarks on the Paleoecology of Nummulites Voprosy Micropaleontology., Akadademiya Nuuk SSSR, 6:64-72(In Russian) No. 5, pp. 29-43.

Nemkov, G. and Barkhatova, N.N., 1960. Nummulites, Assilines and Operculines of the Grimea and their Importance in the Zoning of Eocene Deposits. Minist. Spcc. Ed. SSSR, Moscow, Higher Edue. Inst. Izvestia, Geol. and Prosp., No. 5, pp. 29-43.

Nuttall, W.L.F., 1925. The Stratigraphy of the Laki Series (Lower Eocene) of Parts of Sind and Baluchistan (India); With a Description of the Larger Foraminifera Contained in Those Beds. Geol. Soc. London, Quart. Jour., Vol. 81, pp. 417-453.

Nuttall, W.L.F., 1926. the Zonal Distribution and Description of The Larger Foraminifera of The Middle and Lower Kirthar Series (Lower Eocene) of Parts of Western India. India Geol. Survey, Rec., Calcutta, Vol. 59, pp. 115-165.

Papp, A., 1959. Nummuliten Aus Dem Untereozan Vom Kuhlgrabess Am Fusse Des Untersberges (Salzburg) Geol. Bundesanst., Verh, No.2, pp. 163-179.

Ruiz De Gaona, M., 1948. La Fauna Principalmente Numulitica De La Serie Teiciaaria Guipuzcoana. Spain, Inst. Invest. Geol. Lucas Mallada, Estud. Geol. Madrid, No. 9, pp. 133-158. 
Said, R. and Kerdany, M.T., 1961. the Geology and Micropalentology of the Farafra Qasis, Egypt Micropalentology, N.Y., Vol. 7, No. 3, pp. 317-336.

Sampo, M., 1969. Microfacies and Microfossils of Zagros Area South Western Iran(From Pre-Permian to Miocene) E.J. Brill, Leiden, International Sedimentary Petrographical Setries, Vol. Xii, pp.1-102, With 615 Microphtograph on 105 Plates.

Schaub, H., 1951. Stratigraphie Und Palaontologie Des Schierenflysches Mit Besonderer Breucksichtigung Der Paleocaenen Und Untereocaenen Nummulitien Und Assilinen, Schweizerische Palaontogische Abhandlumgen (Memories De ;La Societe Paleontologue Susses), Vol.68, pp.1-222.

Schaub, H., 1962. Uber Einige Stratigraphische Wichtige Nummuliten-Arten. Eclogae Geol. Helv. Vol.55, pp. 529-551.

Schwager, C., 1883. Die Foraminiferen Aus Den Eocaenablagerungen Der Libyschen Wuste Und Aegyptens. Palentograpgica, Bd. 30, pp. 79-154.

Sengupta, B.K., 1965. Morphology of Some Key Species of Nummulites From the Indian Eocene. Jour. Paleont., Vol. 39, No. 1, pp. 86-96.

Sharbazheri, Kh.M.E., 1983. Study of Foraminifera and Microfacies of the Avanah Limestone (Middle Eocene), Dohuk Area, North Iraq. Unpublished M. Sc. Thesis, Mosul University. College of Science, Iraq.

Silvestri, A., 1939. Foraminifera Dell 'Eocene Della Somalia; Pt.II. In; Paleontologia Della Somalia. Palaeontogr. Italica. Siena, Italy, Vol. 32, Suppl. 4, pp. 1-102.

Silvestri, A., 1942. Foraminifera Dell 'Eocene Della Somalia; Pt.III, Facies.1. in; Paleontologia Della Somalia. IV-Fossili Dell 'Eocene. Palaeontogr. Italica. Pisa, Italy, Vol. 32, Suppl. 5, pp.1-94.

Sissakian, V. K., 1997.Geological Map of Arbeel And Mahabad Quadrangles. Sheets NJ38-14 and NJ-38-15., Scale 1:250000, State Establishment of Geological Survey and Mining. GEOSURV, Baghdad, Iraq.

Sissakian, V.K., 2005. the Stratigraphy of the Exposed Cretaceous Rocks in Iraq, As Deduced From the Results of the Regional and Detailed Geological Survey (Geosurv 1971-1996). Iraqi Bulletin of Geology and Mining.Baghdad.Vol.1, No.1, pp. $1-20$.

Smont, A.H., 1954. Lower Tertiary Foraminifera of the Qatar Peninsula, London, British Mus. (Natural History), pp. 1-96.

Sowerby, J.De., 1840. in; Sykes, W.H. A Notice Respecting Some Fossils Collected in Cutch By Caspt. Walter Smee, of the Bombay Army. Transactions of the Geological Society of London, Vol. 5, pp.317-329.

Viali, V., 1951. L Foraminiferi Luteziano Priaboniani Del Momi Orobio (Adde Di Paverno) Soc. Ital. Sci. Nat. Milan. Italy. Vol.90, No. 2-3, pp.97-168. 